European Journal of Business and Innovation Research

Vol.8, No.2.pp. 1-19, April 2020

Published by ECRTD-UK

Print ISSN: 2053-4019(Print), Online ISSN: 2053-4027(Online)

\title{
CAN STRATEGIC ENTREPRENEURSHIP SUSTAIN THE MARKET SHARE OF NIGERIAN TEXTILE MANUFACTURING FIRMS?
}

\author{
Tijani, O. O. ${ }^{1}$ \\ School of Management Sciences, \\ Department of Business Administration and Marketing, \\ Babcock University, Ilishan-Remo, Ogun State, Nigeria \\ Corresponding Author: tijaniomobolanle00@gmail.com
}

\begin{abstract}
This paper investigates how strategic entrepreneurship triggers and sustain market share with emphasis on strategic flexibility, adaptability, innovation, strategic leadership, risk taking and dynamic capabilities. The study utilized quantitative method through cross-sectional research design. Primary data were sourced through an adapted questionnaire. Internal consistency confirmed the reliability of the instrument while the content, construct, and criterion validity were acknowledged. Out of the fifteen textile firms in Lagos State, three textile manufacturing organizations were purposively selected with a population of 253 senior management employees. Total enumeration was applied and 237 copies of the questionnaire were retrieved. An econometric model was developed and multiple regression was applied as data analysis method. The findings indicated that strategic entrepreneurship has a significant effect on market share (adjusted $R^{2}=0.353\left(F_{(6,230)}=22.444, p=0.000\right)$. However, the individual coefficient results, identified dynamic capabilities, strategic flexibility and adaptability to have exhibited positive and significant effect on firm profitability. The study recommended institutionalization of adaptive inventiveness, litheness in the areas of adaptability, strategic flexibility, and dynamic capabilities to sustain market share.
\end{abstract}

KEYWORDS: dynamic capabilities, market share, strategic entrepreneurship, strategic flexibility

\section{INTRODUCTION}

Globally, firms are being concerned with the performance of their enterprise and efforts are been geared on dominating large market share to ensure the sustainability of their enterprise. As such, businesses embed sustainability to generate positive side effects such as business risks minimization, increases reputation and attractiveness for new or existing talents, respond to new customer demands and segments, thereby increasing market positions, competitiveness and gaining more market share (Dyllick \& Muff, 2016). Moreover, Durotoye, Adeyemi, Omole, and Onakunle (2018) observed that firm's incapability to proliferate their market share was due to the challenges they encountered exclusively from the environment. In the same vein, Idowu, Irefin, and Akarakiri, (2018) also established that the challenges confronted by firms is caused by their failure to sustain the business which has resulted to the industry's poor performance and botch to attain their goals. The goals include market share as it has been regarded as performance parameters for firms (Sulaeman, Tisnawatisule, Hilmiana, \& Cahyandito, 2018) which is attainable through strategic entrepreneurship. 
European Journal of Business and Innovation Research

Vol.8, No.2.pp. 1-19, April 2020

Published by ECRTD-UK

Print ISSN: 2053-4019(Print), Online ISSN: 2053-4027(Online)

Scholars have postulated that for a firm to achieve and sustain its market share, strategic entrepreneurship is a fundamental practice for organisations (Makinde \& Agu, 2018; Ogbari, Obigbemi, Atolagbe, \& Ojo, 2016). Similarly, Durotoye et al. (2018), Ukenna, Makinde, Akinlabi, and Asikhia (2019) also emphasized that strategic entrepreneurship results in superior firm performance in a highly turbulent environment for the sole goal of enhancing the market share of the firm. In Nigeria, scholars (Chukwu, Liman, Enudu, \& Ehiaghe, 2015; Murtala, Ramatu, Yusuf, \& Gold, 2018; Okeowo, 2017) identified low market share of the textile sector given the record of poor leadership, problem of inputs supply, demand, and price competitiveness of the Nigerian textile sector, lack of supportive infrastructure, smuggling and high cost of production which has sent many textile firms in Nigeria into catalepsy.

Preceding studies examined strategic entrepreneurship and market share in SMEs, manufacturing firms, agricultural sector and health sectors of diverse countries (Bature, Sallehuddin, Rosli, \& Saad, 2018; Cuervo, Ribeiro, \& Roig, 2015; Giniuniene \& Jurksiene, 2015; Lee \& Kim, 2013; Morgan, 2009; Ogechi, 2016; Okunbanjo, Adewale, \& Akinsulire, 2017; Sarutaya, 2015; Serfontein, 2010; Takahashi \& Semorebon, 2017; Wang, Tsui, \& Xin, 2011). However, some of these studies found significant relationship between the variables under study, while some result found no relationship. Moreover, past studies on strategic entrepreneurship and market share are dearth in the Nigeria textile sector (Ogechi, 2016; Okunbanjo et al., 2017).

Furthermore, the lack of patronage of Nigerian products due to its high cost affects the market share of the textile sector in Nigeria (Okeowo, 2017). According to the Nigeria Textile Manufacturing Association [NTMA] (2019), the textile market is been dominated by smuggled products and imported fabrics and this has led to a significant reduction in the number of functional manufacturing textile industries in the country which has resulted to the drastic decline in the market share of Nigeria textile sector. Moreover, NTMA (2019) also asserted that 85\% of smuggled textile sold in Nigeria has ensued in the country's loss of $\$ 325$ million in potential Value Added Tax revenue annually and an estimated annual bill of $\$ 1.2 \mathrm{bn}$ from smuggled apparel by the Q4 of 2019. Similarly, within 1992 to 1995 the estimated number of textile manufacturing firms in Nigeria was 124, from 1996 to 1999, the number declined to 112, from 2000 to 2003, 60 from 2004 to 2007, 45 from 2008 to 2011, Nigeria had 40 textile firms, from 2012 to 2015 Manufacturers Association of Nigeria (MAN, 2018), the firms in the industry further reduced to a total of 25 as at 2019 which are operating below capacity with low performance (NTMA, 2019). The situation also created a significant loss of jobs within the industry has employment fell from 60,000 in 2002, to 24,000 in 2010 and approximately 20,000 in 2016 (Okeowo, 2017).

The need for every firm to have a considerable share in the market is very crucial. For business or organization to continue to be sustained, the share of the business or organization in the market must be large and have positive growth trend. Kogo and Kimencu (2018) examined organisational capability and performance of insurance companies and the findings showed that firm capability dimension influenced market share as an indicator of performance positively. Similarly, Takahashi and Semorebon (2017) examined dynamic capabilities as a dimension of strategic entrepreneurship and organisational performance and revealed that dynamic capabilities influence market share only when mediated by marketing ability. Moreover, Sarutaya (2015) earlier observed a positive effect 
European Journal of Business and Innovation Research

Vol.8, No.2.pp. 1-19, April 2020

Published by ECRTD-UK

Print ISSN: 2053-4019(Print), Online ISSN: 2053-4027(Online)

of dynamic capability on market share. In addition, Lee and Kim (2013) in their study on innovation as a dimension of strategic entrepreneurship and market share revealed that technological capability positively influence market share.

Moreover, previous scholars in their studies indicated that strategic leadership positively correlate with market share (Ahmed, 2013; Peterson, Galvin, \& Lange, 2012). Furthermore, Okunbanjo, Adewale, and Akinsulire (2017) found that risk taking enhances firms' market share. In the study of Beraha, Bingol, Ozkan-Canbolat, and Szczygiel (2018), it asserted that strategic flexibility plays a crucial role in firm's market share. It is observed that most of the past studies finding move in the same direction with market share positively. It is on this proposition that this paper seeks to ascertain the effect of strategic entrepreneurship on market share of textile manufacturing firms in Lagos State Nigeria. The paper is structured as a literature review after the introduction, methodology, the results presentation, conclusion, and recommendation.

\section{LITERATURE REVIEW}

This section reviews germane literature in line with the objective of the work. The review allied the independent variables and the dependent variable conceptually, empirically and theoretically to excavate the understanding of the connections among the variables. As such, the dimensions of strategic entrepreneurship were conceptually reviewed before the empirical discourse on the constructs.

\section{Market Share}

According to Khantimirov (2017), market share reflects how marketing expenditures contribute to stakeholders' value. As a measure of marketing productivity, market share is also linked with the overall firm's profitability. Identifying market is the biggest pitfall of market share concept. Market shares grasp the attention of corporate leaders as key guides for measuring the performance of a product or brand in the market. It is the proportion of the over-all sales size in a market taken by a brand, product, or company (Micheal, 2016). In the same vein, Etale, Bingilar, and Ifurueze (2016) orated that market share is the fraction of the entire sales volume in a market apprehended by a product, invention or business. Market share is the consequences of competence of the firm rather than its cause. Dissimilarities in profitability among organisations are due to advanced proficiency. Competent firms that obtain huge market share and earn extraordinary profits induce a causal association between size and profitability (Woo \& Cooper, 2011). Organisations proposing products that offer customers superior value relish gains in market share. Bettermanaged companies that have a competitive advantage propagate faster than opponent firms do. Organisations with grander skill and anticipation gain market share through inferior prices or through improved products (Adefulu, 2015).

Market share is a crucial indicator of market competitiveness- that is, how well an organisation is doing alongside its opponents. Significantly, market share should be closely scrutinized for signs of alteration in the competitive scenery; this picture commonly drives strategic or tactical activities, since it is measured relatively to the competitors' share of customer (Khantimirov, 2017). Cooper and Nakanishi (2014) discovered that though market shares are adopted as market performance indices, it is however clearly necessary for the personalities concerned to have in- 
European Journal of Business and Innovation Research

Vol.8, No.2.pp. 1-19, April 2020

Published by ECRTD-UK

Print ISSN: 2053-4019(Print), Online ISSN: 2053-4027(Online)

depth understanding of the process which generates market share figures and be competent to evaluate the influence of their own activities on market shares as well as their profit insinuations. The study therefore, referred market share as the number of customer patronage of an organization's products or services in a specific market place.

\section{Strategic Entrepreneurship}

Strategic entrepreneurship integrates both strategic management and entrepreneurship. Strategic Entrepreneurship designates the connotation amid entrepreneurship and strategic management (Kuratko \& Audretsch, 2009). Ukenna, Makinde, Akinlabi, and Asikhia (2019) defines strategic entrepreneurship as a routine that necessitates organisational exertions to distinguish opportunities with the maximum prospective to lead, formation of value via the entrepreneurial component, exploit them through measured pre-emptive actions, based on the organisational resources. Conferring to Paek and Lee (2017) strategic entrepreneurship is a business's tactical intent to continuously and carefully clout entrepreneurial opportunities for firm's development and benefit. Similarly, Haddawee (2018) concurred with the study of Paek and Lee (2017) and emphasised that strategic entrepreneurship incorporates the amalgamation of the entrepreneurial (opportunity seeking) views and strategic (competitive-advantage seeking) outlooks besieged at the enactment of entrepreneurial short, mid and long-term guidelines to assuage risks, yield value and wealth for the shareholders and society. Dogan (2015) and Paek and Lee (2017) asserted that strategic entrepreneurship can be institutionalized at individual-level perceptions and corporate opportunities in the form of firm-level strategies which enhances growth. This paper delineates strategic entrepreneurship in line with organisation's strategic flexibility, adaptability, innovation, strategic leadership, risk taking and dynamic capabilities.

\section{Innovation}

Vyas (2009) broadly sees innovation as formation of new products or qualitative enhancement in current products; process of using a new industrialised process; opening a new market; developing a new raw material, establishment of new organization. In addition, Bature, Sallehuddin, Rosli, and Saad (2018) and Covin and Miller (2014) define innovation as the readiness of business establishments to come up with different concepts in terms of processes/procedures or products in the marketplace. Similarly, Lomberg, Urbig, Stöckmann, Marino, and Dickson (2017) earlier referred to innovation as the inclination of business enterprises to indoctrinate the spirit of creating inventive thoughts or processes to introduce new products or services through research or feasibility study. Innovation is defined as enactment of a new production or delivery method or significant enhancement in offered value perceived by end user (Howell, 2018); it is also a process that is designed and managed to create value that comes out better in the form of services, products, processes, technologies, and business systems by the firm (Shouyu, 2017). Thus, the study sees innovation as the formation and/or modification of organisational products or services as well as production/service delivery techniques in order to achieve organisational goals and objectives.

\section{Strategic Leadership}

Strategic leadership is regarded by Jaleha and Machuki (2018) and Kabetu and Iravo (2018), as a set of distinctive proficiencies of expecting, envisaging, sustaining flexibility, thinking in a tactical 
European Journal of Business and Innovation Research

Vol.8, No.2.pp. 1-19, April 2020

Published by ECRTD-UK

Print ISSN: 2053-4019(Print), Online ISSN: 2053-4027(Online)

way, and permitting employees to spawn inventive ideas that lead to extraordinary performance. Strategic leadership is dissimilar from the general conception of leadership. According to Funda and Cihan (2014), strategic leadership focuses on officials who have general obligation for a business, their features, what they do, how they do it, and mostly, how they influence firm's results. Nyamao (2016) concurred with Funda and Cihan (2014) and attributed the focuses on the future, to generate enthusiasm for the future, and for present event. Alhyasat and Sharif (2018) further asserted that the focus is on leaders' competencies of creating a sense of determination and direction that allow integration and interface with key internal and external environment in pursuit of sound performance. Therefore, this study sees strategic leadership as the ability of an organisational leader to predict, envisage, and maintain flexibility to empower the subordinate in creating strategic change as necessary to sustain the organization.

\section{Risk Taking}

Risk taking involves taking bold steps, by entering into the uncertain business environment and borrowing heavily (Eze, 2018). Similarly, risk-taking involves firms' inclination to assume courageous acts such as assigning a tangible amount of resources to ventures with doubtful outcomes, venturing into unfamiliar markets, as well as the proclivity to borrow heavily with the anticipation of reaping high returns (Etebang, Harrison, \& Ernest, 2010; Lawal, Adegbuyi, Iyiola, Ayoade, \& Taiwo, 2018). Risk taking is a firm's disposition to embark on innovative projects irrespective of how uncertain such business activity is (Kallmuenzer \& Mike, 2018). Adisa, Adeoye, and Okunbanjo (2016) revealed that risk taking is all about taking courageous actions by venturing into the unfamiliar, appropriating large, and or compelling substantial resources to ventures in undefined regions. Based on the diverse definition and concept of risk taking, this study sees risk taking as the activities that an organisation engages in without any assurance of the success of the activities.

\section{Dynamic Capabilities}

Dynamic capabilities refer to the (incomparable) aptitude organisations have to form, reform, organize and reconfigure the company's asset base in order to counter the fluctuating technologies and markets (Augier \& Teece, 2014). Dynamic capability does not only includes the firm's (unique) capability to sense altering consumer needs, technological prospects, and competitive expansions; but also its aptitude to acclimatize to - and perchance even to shape - the business environment in a suitable and effectual manner. To achieve this, the firm needs to retain the capability to nous and then grasp opportunities, steer threats, pool and reconfigure specialized and co-specialized assets (Teece, 2019). However, Alpha and Vincent (2015) referred dynamic capabilities to the firm's aptitude to accomplish new forms of competitive benefit, that is, an establishment's reactivity and flexibility to market oscillations. This study defined dynamic capabilities as an act in which an organisation continuously builds and reconfigures its operational capabilities faster in an affordable way to achieve effectiveness and efficiency.

\section{Strategic Flexibility}

Supeno, Sudharma, Aisjah, and Laksmana (2015) defined flexibility as a way of amassed control in an extremely blustery environment. Flexibility is contingent upon the increasing firm's capacity to change or exploit opportunities created in the context of environmental dynamism and can be 
European Journal of Business and Innovation Research

Vol.8, No.2.pp. 1-19, April 2020

Published by ECRTD-UK

Print ISSN: 2053-4019(Print), Online ISSN: 2053-4027(Online)

viewed as the corporate specific skill or a resource (Doroudi \& Babaei, 2016). Firm flexibility can be considered a strategic option where predicting the environment is challenging. It is positioned to be used as a tool to control in a highly uncertain environment (Bishwas \& Sushil, 2013; Yazan, 2018). In the same vein strategic flexibility is the capability of a firm to identify the dynamics of environment and tap into the sources fast to begin new operation to react to these dynamics which leads to enhanced innovation performance (Ibidunni \& Inelo, 2015; Kamasaka, Yavuzb, Karagulle, \& Agcad, 2016; Yazan, 2018). Strategic flexibility is perceived in this study as an organisation's ability in analysing the forces of its external business environment as well as taking strategic actions that will make the organisation to be more proactive against changes in the business environment.

\section{Adaptability}

Adaptability is a multidimensional concept that incorporates a range of intellectual skills and conducts that leaders improve in themselves and indoctrinate in their organisations through edification, training, and experience. Battilana and Casciaro (2012) posited that individual adaptability does not spontaneously transfer to organisational adaptability. According to Boylan and Turner (2017), emerging organisations capability of adapting necessitates dynamic leadership that nurtures a philosophy that values communal adaptability. Leaders who institute stiff and intransigent organisational systems, processes, and activities asphyxiate adaptive and creative individuals by quelling new ideas and change (Battilana \& Casciaro, 2012). To benefit from individual adaptability, leaders must cultivate organisations that can acclimatize to the perpetually changing environment. An organisation adept of adapting is one that can both antedate and counter to variations in the environment (Klein \& Pierce, 2001).

\section{Strategic Entrepreneurship Sub Variables and Market Share.}

Pleshko and Heiens (2012) examined the market share impact of the fit between market leadership in the context of strategic entrepreneurship and overall strategic aggressiveness and concluded that market leadership and strategic aggressiveness have significant contributions to market share. In the same vein, Gelard and Ghazi (2014) results showed that strategic entrepreneurship has direct impact on market growth of firms. Similarly, Cuervo, Ribeiro, and Roig (2015) concurred with the study of Kraus, Rigtering, Hughes, and Hosman (2012), both studies investigated the effect of strategic entrepreneurship and market share during the period of economic crisis. Their studies revealed that entrepreneurial mind-set was positively significant to market share. The implication of such conclusion is that the lack of effective entrepreneurship have an adverse impact on market share.

Erstwhile studies convened that dynamic capabilities, risk taking, strategic flexibility, strategic leadership and innovation which are dimensions of strategic entrepreneurship also revealed a positive impact on market share as seen in the study of Okunbanjo et al. (2017) which showed that risk taking is significantly correlated to market share. The study of Giniuniene and Jurksiene (2015) and Sarutaya (2015) both revealed that there is a positive effect of dynamic capability on market share. Takahashi and Semorebon (2017) proceeded to examine dynamic capabilities, marketing capability and organisational performance and the result was almost similar to the study of Giniuniene and Jurksiene (2015) and Sarutaya (2015) but was different as dynamic capabilities 
European Journal of Business and Innovation Research

Vol.8, No.2.pp. 1-19, April 2020

Published by ECRTD-UK

Print ISSN: 2053-4019(Print), Online ISSN: 2053-4027(Online)

have influence on market share only when mediated by marketing ability. Moreover, the studies of Morgan (2009), Theodosiou, Kehagias, \& Katsikea (2012) and Vorhies, Morgan, and Autry (2009) had earlier established that dynamic capability and market share were positively related.

On one hand, Garrett, Covin, and Slevin (2009) studied risk taking as a dimension of strategic entrepreneurship and market share and found that risk taking positively predict the intensity of an organisation's market share. On the other hand, the results of Rubera and Kirca (2012) revealed that there is a positive effect of firm innovativeness on market position. Conversely, the results of Pleshko and Heiens (2012) indicated that strategic leadership negatively impact on market share. However, Ahmed (2013) and Peterson, Galvin, and Lange (2012) indicated that strategic leadership is positively correlated with market share as proxy for performance. Equally, Supriyadi (2017) examined the influence of strategic leadership on firm inventive and innovative performance in the market and the results showed that there is positive association between strategic leadership and market performance of inventive products.

In the same vein, Ibrahimpour-Azbari (2015) found that strategic flexibility as an indicator of strategic entrepreneurship positively and significantly affect the market innovation which, in turn, has a positive and significant effect on the market performance, in the author's study on effect of strategic flexibility on the firms market performance. Furthermore, the position of IbrahimpourAzbari (2015) was corroborated by Beraha, Bingol, Ozkan-Canbolat, and Szczygiel (2018) on strategic flexibility on market share of new products and asserted that strategic flexibility plays a crucial role in firm's market share. Liyanage and Weerasinghe (2018) also confirmed the findings of Beraha, Bingol, Ozkan-Canbolat, and Szczygiel (2018) that strategic flexibility has a strong association to performance. However, Patil and Marathe (2016) findings suggested that market orientation and planning flexibility positively affect firm performance while planning flexibility wields a negative force on performance in highly dynamic markets. The lack of consensus among past studies were attributed to the diversified geographical region in which the study were conducted and the different indicators of strategic entrepreneurship.

\section{METHODOLOGY}

This study utilized the cross-sectional survey research design with the insistence of retrieving data to make extrapolations about a population of concern (universe) at a single point in time. The validation for the choice of cross-sectional survey is dependable with the studies of Ukenna et al (2019), Mohammed, and Obeleagu-Nzelibe (2014). This study was steered in Lagos State Nigeria and out of the 15 textile firms operating in the state, only three were qualified based on the criteria established; functioning below $20 \%$ production capacity, not importing finished products, and have been in existence for more than twenty years. The manufacturing companies comprises of Wollen and Synthetic Textile Ltd, Nichemtex Textile Ltd, and Sunflag Textile Ltd. The population entail of two hundred and fifty three (253) senior management employees of the textilemanufacturing firms in Lagos State. The senior management employees were nominated because they are intricate in strategic decisions in an organization. The study utilized total enumeration of the senior management employees due to the small population. 
Vol.8, No.2.pp. 1-19, April 2020

Published by ECRTD-UK

Print ISSN: 2053-4019(Print), Online ISSN: 2053-4027(Online)

The paper adopted primary source of data through a structured questionnaire. The items in the questionnaire were adapted; items on innovation and strategic flexibility (Ghorban-Bakhsh \& Gholipour-Kanani, 2018); strategic leadership (Norzailan, Yusof, \& Othman, 2016); dynamic capability (Augier \& Teece, 2014); risk taking (Holtzhausen \& Naidoo, 2016); adaptability (Ployhart \& Bliese, 2006) and market share (Ukenna et al., 2019). The questionnaire was divided into three sections: Section A addresses the demographic, section B and C assess question items on strategic entrepreneurship and market share, respectively. Pilot study was conducted to ascertain the validity and reliability of the instrument in order to determine if the instrument measures what it is meant to measure and its internal consistence. Validity test was carried out using Kaiser-Meyer-Olkin (KMO) test and reliability test through Cronbach's alpha coefficient with result indicating $(\alpha)=0.78$ (with the lowest being 0.751 ; and the highest 0.853 ) and was judged reliable since Cronbach's alpha was greater than 0.70 and closer to 1.0 (Nunnally, 1978). Therefore, the multiple regression equation was established based on the objective of the study.

\section{Model Specification}

Hence the regression model was formulated in relation to the objective;

$Y=f(X)$

Where:

$\mathrm{Y}=$ Market Share $(\mathrm{MS})$

$\mathrm{X}=$ Strategic Entrepreneurship (SE)

The functional relationship of the model is presented as:

$\mathrm{MS}=\mathrm{f}(\mathrm{SE})$

$\mathrm{MS}=\mathrm{f}(\mathrm{IN}, \mathrm{SL}, \mathrm{RT}, \mathrm{DC}, \mathrm{SF}, \mathrm{AD})$

Hence,

$M S=a+\beta_{1} I N_{i}+\beta_{2} S L_{i}+\beta_{3} R T_{i}+\beta_{4} D C_{i}+\beta_{5} S F_{i}+\beta_{6} A D_{i}+\mu_{i}$

Where:

$\mathrm{a}=$ constant of the equation or constant term i.e. the level of market share when strategic entrepreneurship is not available or zero.

$\beta_{1}-\beta_{6}=$ Parameters to be estimated

$\mathrm{IN}_{\mathrm{i}}=$ Innovativeness, $\quad \mathrm{SL}_{\mathrm{i}}=$ Strategic Leadership, $\quad \mathrm{RT}_{\mathrm{i}}=$ Risk Taking

$\mathrm{DC}_{\mathrm{i}}=$ Dynamic Capabilities, $\quad \mathrm{SF}_{\mathrm{i}}=$ Strategic Flexibility, $\quad \mathrm{AD}_{\mathrm{i}}=$ Adaptability

$\mu=$ error or stochastic term i.e. the value of other extraneous variables not included in the model.

Ethical issues in research were prioritized in accord with her rules and guidelines recognised in areas of guaranteeing obscurity of the respondents, privacy and undue data manipulation. Honesty in data processing, data reporting, result reporting and no false data are included in the data presentation and interpretation. 
European Journal of Business and Innovation Research

Vol.8, No.2.pp. 1-19, April 2020

Published by ECRTD-UK

Print ISSN: 2053-4019(Print), Online ISSN: 2053-4027(Online)

\section{RESULTS AND DISCUSSIONS}

From a total of 253 distributed copies of questionnaire, 237 copies were properly filled and returned. The descriptive statistics and inferential statistics results and findings are presented below in line with the objective of the paper.

Table 1 Descriptive analysis Result on each Variable

\begin{tabular}{llll}
\hline & Variables & Mean & Standard Deviation \\
\hline 1 & Innovativeness & 4.31 & 0.883 \\
2 & Strategic Leadership & 4.29 & 0.924 \\
3 & Risk Taking & 4.28 & 0.97 \\
4 & Dynamic Capabilities & 4.22 & 0.92 \\
5 & Strategic Flexibility & 4.38 & 0.942 \\
6 & Adaptability & 4.18 & 1.022 \\
7 & Market Share & 4.00 & 1.06 \\
\hline
\end{tabular}

Source: Field Survey, 2019

Table 1 presents the results of descriptive statistics of the study. The average score of the items for innovativeness is 4.31 with a standard deviation of 0.883 which means that on average the respondents revealed that innovativeness is moderately high in textile manufacturing firms in Lagos State, Nigeria. The average score of the items for strategic leadership is 4.29 with a standard deviation of 0.924 which means that on average the respondents revealed that strategic leadership is moderately high in the textile manufacturing firms in Lagos State, Nigeria. The average score of items to measure risk taking is 4.28 with a standard deviation of 0.97 which means that on average, the respondents opined that risk taking is moderately high in the textile manufacturing firms in Lagos State, Nigeria. The average score of the items to measure dynamic capabilities is 4.22 with a standard deviation of 0.92 which means that on average the respondents indicated that dynamic capabilities is moderately high in the textile manufacturing firms in Lagos State, Nigeria. The average score of items to measure strategic flexibility is 4.38 with a standard deviation of 0.942 which means that on average the respondents indicate that strategic flexibility is moderately high in the textile manufacturing firms in Lagos State, Nigeria. The average score of the statements for adaptability is 4.18 with a standard deviation of 1.022 which means that on average the respondents indicated that adaptability is moderately high in the textile manufacturing firms in Lagos State, Nigeria. Table 1 also indicated that strategic entrepreneurship sub-variables and market share have the same pattern of increase. The findings discovered that the respondents' measures of strategic entrepreneurship sub-variables and market share are moderately high. This suggests that strategic entrepreneurship sub-variables could improve market share of textile manufacturing firms in Lagos State, Nigeria.

The dispute of this paper is that strategic entrepreneurship factors affect market share which was tested through a multiple regression analysis and results are shown in Table 2. 
European Journal of Business and Innovation Research

Vol.8, No.2.pp. 1-19, April 2020

Published by ECRTD-UK

Print ISSN: 2053-4019(Print), Online ISSN: 2053-4027(Online)

Table 2: Summary of multiple regression analysis for effects of strategic entrepreneurship on market share of textile manufacturing companies in Lagos State, Nigeria

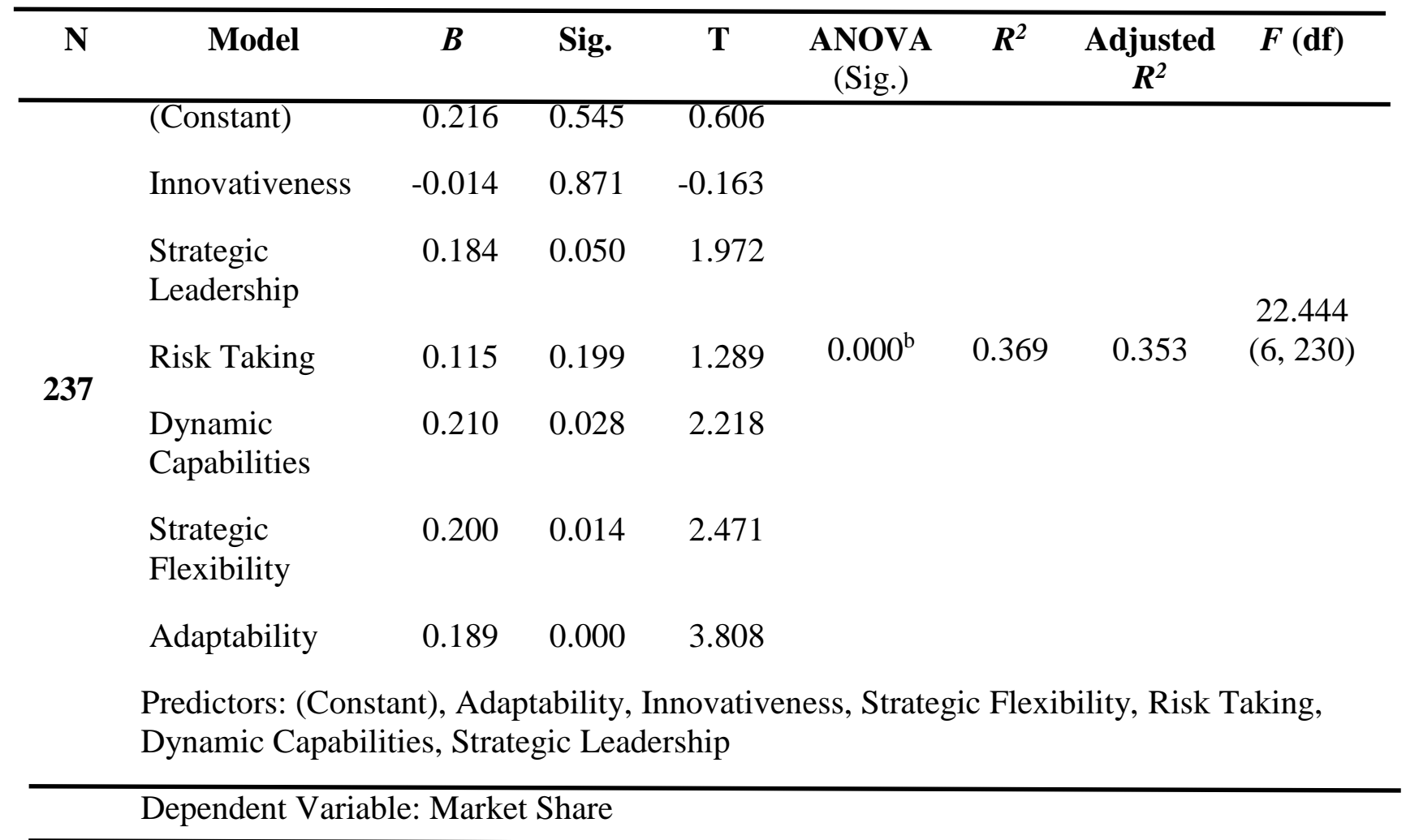

Source: Field Survey, 2019

\section{Interpretation}

The analysis in Table 2 presents the result of the multiple regression analysis on the effect of strategic entrepreneurship sub-variables (innovativeness, strategic leadership, risk taking, strategic flexibility and adaptability) on market share of textile manufacturing companies in Lagos State, Nigeria. The coefficient of multiple determination, adjusted $R^{2}$ is $0.353\left(F_{(6,230)}=22.444, p=0.000\right)$ indicates that strategic entrepreneurship sub-variables explained $35.3 \%$ of the changes in market share of the textile manufacturing companies in Lagos State, Nigeria while the remaining 64.7\% could be attributed to other factors not included in this model. Also, the $F$-statistics $(\mathrm{df}=6,230)$ $=22.444$ at $p=0.000(p<0.05)$ indicates that the overall model is significant in predicting the effect of strategic entrepreneurship sub-variables on market share. This implies that strategic entrepreneurship sub-variables have a significant effect on market share of textile manufacturing companies in Lagos State, Nigeria.

In addition, Table 2 showed the individual multiple regression analysis. The result of the analysis indicated that, dynamic capabilities $(\beta=0.210, \mathrm{t}=2.218, p<0.05)$, strategic flexibility $(\beta=0.200$, $\mathrm{t}=2.471, p<0.05)$ and adaptability $(\beta=0.189, \mathrm{t}=3.808, p<0.05)$ have positive and significant effect on market share of textile manufacturing companies in Lagos State, Nigeria. The result further showed that strategic leadership $(\beta=0.184, \mathrm{t}=1.972, p>0.05)$ and risk taking $(\beta=0.115$, 
European Journal of Business and Innovation Research

Vol.8, No.2.pp. 1-19, April 2020

Published by ECRTD-UK

Print ISSN: 2053-4019(Print), Online ISSN: 2053-4027(Online)

$\mathrm{t}=1.289, p>0.05)$ have positive and insignificant effect on market share while innovativeness $(\beta$ $=-0.014, \mathrm{t}=-0.163, p>0.05)$ has a negative and insignificant effect on market share of textile manufacturing companies in Lagos State, Nigeria. The result inferred that out of all the subvariables of strategic entrepreneurship, only dynamic capabilities, strategic flexibility and adaptability have significant effect on market share which implies that only these sub-variables are important determinants of market share of the textile manufacturing companies in Lagos State, Nigeria.

The multiple regression model is expressed as thus:

$M S=0.216+0.210 D C+0.200 S F+0.189 A D \ldots \ldots$ eq. $\mathrm{i}$

Where:

MS = Market Share

$\mathrm{DC}=$ Dynamic Capabilities

$\mathrm{SF}=$ Strategic Flexibility

$\mathrm{AD}=$ Adaptability

The regression model shows that holding strategic entrepreneurship sub-variables to a constant zero, market share would be 0.216 . This means that without strategic entrepreneurship subvariables, market share would be positive at 0.216 indicating an improvement. The analysis also showed that when dynamic capabilities, strategic flexibility and adaptability are improved by one unit, market share would increase by $0.210,0.200$ and 0.189 respectively. This indicates that an increase in dynamic capabilities, strategic flexibility and adaptability would lead to a subsequent increase in market share of textile manufacturing companies in Lagos State, Nigeria. The result of the analysis indicates that textile manufacturing companies should focus on dynamic capabilities, strategic flexibility and adaptability to increase their market share.

\section{DISCUSSION OF FINDINGS}

The findings of this paper that strategic entrepreneurship sub-variables have no significant effect on market share of textile manufacturing firms in Lagos State, Nigeria revealed that strategic entrepreneurship sub-variables have a significant effect on market share of textile manufacturing companies in Lagos State, Nigeria. The finding of this study affirmed the position of past studies that strategic entrepreneurship influence the market share of firm (Cuervo, Ribeiro, \& Roig, 2015; Lee \& Kim, 2013; Okunbanjo, Adewale, \& Akinsulire, 2017; Takahashi \& Semorebon, 2017).

Conceptually, this finding is supported with the study of Pleshko and Heiens (2012) that market share impact of the fit between market leadership in the context of strategic entrepreneurship and overall strategic aggressiveness and concluded that market leadership and strategic aggressiveness have significant contributions to market share. Corroborating the study of Pleshko and Heiens 
European Journal of Business and Innovation Research

Vol.8, No.2.pp. 1-19, April 2020

Published by ECRTD-UK

Print ISSN: 2053-4019(Print), Online ISSN: 2053-4027(Online)

(2012) is the findings of Gelard and Ghazi (2014) which indicated that strategic entrepreneurship has direct impact on market growth of firms especially when the firm is able to adapt to the turbulent environment and be flexible in its approaches in solving issues or situations in the firm.

Empirically, Cuervo, Ribeiro, and Roig (2015) concurred with the study of Kraus, Rigtering, Hughes, and Hosman (2012), both studies revealed that entrepreneurial mind-set was positively significant to market share. The implication of such conclusion is that the lack of effective entrepreneurship have an adverse impact on market share. Irrespective of the dynamic environment and the existing economic crisis, strategic entrepreneurship augments market share. In addition, Khantimirov (2017) asserted that the ability of an organization to utilize its marketing expenditures and adopt situational strategies reflects on the firm's market share which also ensures the sustainability of the firm.

The result of Westgren and Wuebker (2019) also substantiated with the findings of this study that strategic entrepreneurship amplifies firm's market share. The ability of a firm to employ strategic entrepreneurship into its daily activities and running of the organization ensures large market share of the firm. In addition, the growth in market share in relation to competitors; a company with growth in market share was growing revenue faster than other firms in the same industry. In line with this, Amar, Syariati, and Rahim (2019) opined that continuous and frequent launch of new/improved products, maintenance and continuous improvement of quality products, high level of activity by the sales force and the adoption of strategic entrepreneurship practices improves the market share of the firm.

On the other hand, the individual coefficient results revealed that dynamic capabilities, strategic flexibility and adaptability have positive and significant effect on market share of textile manufacturing companies in Lagos State, Nigeria. This was also affirmed by the study of Giniuniene and Jurksiene (2015) and Sarutaya (2015) which revealed that there is a positive effect of dynamic capability on market share. Similarly, the findings of Takahashi and Semorebon (2017) corroborated the results of Giniuniene and Jurksiene (2015); Sarutaya (2015) and the finding of this study that dynamic capabilities have significant influence on market share especially when it is mediated by marketing ability. Moreover, the earlier studies of Morgan (2009), Theodosiou, Kehagias, \& Katsikea (2012) and Vorhies, Morgan, and Autry (2009) also concurred with the findings of this study that dynamic capability and market share were positively related.

In the same vein, the result of this study was supported by the findings of Ibrahimpour-Azbari (2015) which found that strategic flexibility as an indicator of strategic entrepreneurship positively and significantly affect the market innovation which, in turn, has a positive and significant effect on the market performance. Additionally, the position of Ibrahimpour-Azbari (2015) was upheld by Beraha, Bingol, Ozkan-Canbolat, and Szczygiel (2018) on the strategic flexibility of market share of new products and asserted that strategic flexibility plays a crucial role in firm's market share. The study was also corroborated by Liyanage and Weerasinghe (2018) which also confirmed that strategic flexibility has a strong association to performance. However, Patil and Marathe (2016) findings suggested that market orientation and planning flexibility positively affect 
European Journal of Business and Innovation Research

Vol.8, No.2.pp. 1-19, April 2020

Published by ECRTD-UK

Print ISSN: 2053-4019(Print), Online ISSN: 2053-4027(Online)

firm performance while planning flexibility wields a negative force on performance in highly dynamic markets.

Moreover, the individual coefficient results revealed that strategic leadership and risk taking have positive and insignificant effect on market share. The finding of this study was corroborated by Ahmed (2013) and Peterson, Galvin, and Lange (2012) which indicated that strategic leadership is positively correlated with market share as proxy for performance. Equally, Supriyadi (2012) results showed that there is positive association between strategic leadership and market performance of inventive products. Similarly, Alhyasat and Sharif (2018) further asserted that the emphasis is on leaders' proficiencies of creating a sense of fortitude and direction that allow amalgamation and interface with key internal and external environment in pursuit of large market share. Conversely, the results of Pleshko and Heiens (2012) indicated that strategic leadership negatively impact on market share. In the same vein, Okunbanjo et al. (2017) indicated that risk taking is significantly correlated to market share. Garrett, Covin, and Slevin (2009) also revealed that risk taking positively predict the intensity of an organisation's market share.

On the other hand, the individual coefficient result revealed that innovativeness has a negative and insignificant effect on market share of textile manufacturing companies in Lagos State, Nigeria. The finding of this study was neglected by the results of Rubera and Kirca (2012) which revealed that there is a positive effect of firm innovativeness on market position. Similarly, Jean, Kim, Chiou, and Calantone (2018) opined that innovation has a significant effect on the market share of a firm since it is the key to victory in the competitive business environment.

This study finding are substantiated by the resource-based view which expresses that firm's assets and capacities that are uncommon, significant, non-substitutable, and defectively imitable structure the reason for an organisations continued sustained competitive advantage which enhances the firms market share in the industry. RBV proposes that the firm can verify a supported sustained competitive advantage through encouraging the improvement of skills that are firm explicit, produce complex social relationship; are inserted in an organization's history and culture, and create inferred business information (Odhong \& Were, 2013). This theory also corroborated the finding of this study that the ability of a firm to utilize its resources, be flexible in its strategies, enhance its dynamic capabilities and adapt to the turbulent environment amplifies the market share of the firm.

\section{CONCLUSION AND RECOMMENDATIONS}

This paper affirms that strategic entrepreneurship has a significant effect on market share of Nigerian textile manufacturing firms operating in Lagos State which is line with the findings of most of the past studies and the assumptions of Resource-based view. However, the individual coefficient results indicated that, dynamic capabilities, strategic flexibility and adaptability have positive and significant effect on market share of textile manufacturing companies in Lagos State, Nigeria. The result further showed that strategic leadership and risk taking have positive and insignificant effect on market share while innovativeness has a negative and insignificant effect on market share of textile manufacturing companies in Lagos State, Nigeria. Based on this finding, 
European Journal of Business and Innovation Research

Vol.8, No.2.pp. 1-19, April 2020

Published by ECRTD-UK

Print ISSN: 2053-4019(Print), Online ISSN: 2053-4027(Online)

the paper concluded that strategic entrepreneurship has a significant influence on market share. Thus, the paper recommended that Nigerian textile manufacturing firms should adopt dynamic capabilities, strategic flexibility and adaptability as strategic entrepreneurship practices to experience exponential market share. Future research should outspread this concept of market share to other non-manufacturing textile firms to expand the insight on strategic entrepreneurship. Also, future researchers could carry out a comparative study of other industries so as to generalize findings.

\section{REFERENCES}

Adefulu, A. D. (2015). Promotional strategy impacts on organisational market share and profitability. Acta Universitatis Danubius, 11(6), 2-17.

Adisa, M. K., Adeoye, A. O., \& Okunbanjo, O. I. (2016). The impact of entrepreneurship orientation on entrepreneur's compensation in Nigeria. International Journal of Economics, Business and Management Studies, 3(3), 102-116.

Ahmed, S. (2013). Effective not-for profit management: Context, concepts, and competencies. New York: CRC Press Taylor \& Francis.

Alhyasat, W. M., \& Sharif, Z. M. (2018). The relationship between strategic leadership and organisation performance in Jordan Industrial Estates Company. AIP Conference Proceedings, 020023.

Alpha, A., \& Vincent, S. (2015). Factors determining firm's strategy of internalization: A case study on Poland. International Journal of Business and Management Review, 3(5), 1-16.

Amar, M. Y., Syariati, A., \& Rahim, F. R. (2019). Enhancing Hotel Industry Performance through Service Based Resources and Strategic Entrepreneurship (Case Study At Hotel Industries In Indonesia). Academy of Entrepreneurship Journal.

Augier, M., \& Teece, D. J. (2014). Dynamic capabilities and the role of managers in business strategy and economic performance. Organisation Science, 20(2), 410-421.

Augier, M., \& Teece, D. J. (2014). Dynamic capabilities and the role of managers in business strategy and economic performance. Organisation Science, 20(2), 410-421.

Battilana, J., \& Casciaro, T. (2012). Change agents, networks, and institutions: A contingency theory of organisational change. Academy of Management Journal, 55(2), 381-398.

Bature, S. W., Sallehuddin, R. M., Rosli, N. A., \& Saad, S. (2018). Proactiveness, innovativeness and firm performance: The mediating role of organisational capability. Academy of Strategic Management Journal, 17(5), 1-14.

Beraha, A., Bingol, D., Ozkan-Canbolat, E., \& Szczygiel, N. (2018). The effect of strategic flexibility configurations on product innovation. European Journal of Management and Business Economics, 27(2), 129-140.

Bishwas, S., \& Sushil, P. (2013). Knowledge management and related emerging issues in organisations: A systems thinking using feedback loop analysis. International Journal of Industrial and Systems Engineering, 5(4), 69-75.

Boylan, S. A., \& Turner, K. A. (2017). Developing organisational adaptability for complex environment. Journal of Leadership Education, 1, 183-198.

Chukwu, B., Liman, N., Enudu, T., \& Ehiaghe, A. (2015). The effect of economic recession in textile manufacturing industries in Nigeria. Asian Journal of Business Management, 7(3), 43-54. 
European Journal of Business and Innovation Research

Vol.8, No.2.pp. 1-19, April 2020

Published by ECRTD-UK

Print ISSN: 2053-4019(Print), Online ISSN: 2053-4027(Online)

Cooper, L. G., \& Nakanishi, M. (2014). Market-Share analysis: evaluating competitive marketing effectiveness. Boston: Dordrecht Kluwer.

Covin, J. G., \& Miller, D. (2014). International entrepreneurial orientation: Conceptual considerations, research themes, measurement issues, and future research directions. Entrepreneurship Theory and Practice, 38(1), 11-44.

Cuervo, A., Ribeiro, D., \& Roig, S. (2015). Entrepreneurship: Concepts, theory and perspective $\left(3^{r d} E d n\right)$. New York: Atlantis Press.

Dogan, L. (2015). The intersection of entrepreneurship and strategic management: Strategic entrepreneurship. Social and Behavioral Sciences, 195, 1288 - 1294.

Doroudi, H., \& Babaei, L. (2016). A study on the relationship between strategic planning processes, planning flexibility, and firm performance: Considering the mediating role of innovation. Proceeding for International Conference on Economy, Management, and Psychology.

Durotoye, T. O., Adeyemi, A. A., Omole, D. O., \& Onakunle, O. (2018). Impact assessment of wastewater discharge from a textile sector in Lagos, Nigeria. Cogent Engineering, 5(1), 111.

Dyllick, T., \& Muff, K. (2016). Clarifying the meaning of sustainable business: Introducing a typology from business-as-usual to true sustainability. Organization \& Environment, 29, 156-174.

Etale, L. M., Bingilar, P. F., \& Ifurueze, M. S. (2016). Market share and profitability relationship: A study of the banking sector in Nigeria. International Journal of Business, Economics and Management, 3(8), 103-112.

Etebang, H., Harrison, R., \& Ernest, C. (2010). Entrepreneurial orientation of public enterprises in Malaysia. Business Strategy Series 11(2), 77-89.

Eze, B. U. (2018). Corporate entrepreneurship and manufacturing firms' performance. Emerging Markets Journal, 8(1), 11-18.

Funda, Ö., \& Cihan T. (2014). Effect of strategic leadership styles on firm performance: A study in a Turkish SME. Procedia - Social and Behavioral Sciences 150, $778-784$

Garrett, R. P., Covin, J. C., \& Slevin, D. P. (2009).Market responsiveness, top management risk taking, and the role of strategic learning as determinants of market pioneering. Journal of Business Research, 62(8), 782-788.

Gelard, P., \& Ghazi, E. (2014). Strategic entrepreneurship element from theory to practice. International Journal of Business and Technopreneurship, 4(2), 205-219.

Ghorban-Bakhsh, R., \& Gholipour-Kanani, Y. (2018). Investigating the impact of strategic flexibility on organisational innovation. International Review of Management and Marketing, 8(3), 1-5.

Giniuniene, J., \& Jurksiene, L. (2015). Dynamic capabilities, innovation and organisational learning: Interrelations and impact on firm performance. Procedia - Social and Behavioral Sciences, 213, $985-991$.

Haddawee, A. H. (2018). The impact of strategic foresight on strategic entrepreneurship. The International Journal of Social Sciences and Humanities Invention 5(5), 4687-4699.

Holtzhausen, J. P., \& Naidoo, V. (2016). Critical assessment of risk-taking behavior and economic performance of male entrepreneurs in the Centurion central business district in South Africa. Investment Management and Financial Innovations, 13(3), 93-104. 
European Journal of Business and Innovation Research

Vol.8, No.2.pp. 1-19, April 2020

Published by ECRTD-UK

Print ISSN: 2053-4019(Print), Online ISSN: 2053-4027(Online)

Howell, A. (2018). Innovation and firm performance in the People's Republic of China: A structural approach with spillovers. Tokyo: Asian Development Bank Institute.

Ibidunni, O., \& Inelo, F. (2015). Market oriented strategic flexibility and market performance of the furniture industry in Southwest Nigeria under fierce competitive environment. Sky Journal of Business Administration and Management, 3(1), 008-016.

Ibrahimpour-Azbari, M. (2015). Examining the effect of strategic flexibility on the firm's market performance: The mediating role of mark innovation. Industrial Technology Development, $13(26), 55-67$.

Idowu, D. J., Irefin, I. A., \& Akarakiri, J. B. (2018). Technology choices in Nigerian textile sector. International Journal of Home Economics, 11(1), 3-8.

Jaleha, A. A., \& Machuki, V. N. (2018). Strategic leadership and organisational performance: A critical review of literature. European Scientific Journal, 14(35), 124-149.

Jean, R. B., Kim, D., Chiou, J. S., \& Calantone, R. (2018). Strategic orientations, joint learning, and innovation generation in international customer-supplier relationships. International Business Review, 27(4), 838-851.

Kabetu, D. G., \& Iravo, M. A. (2018). Influence of strategic leadership on performance of international humanitarian organisations in Kenya. International Academic Journal of Innovation, Leadership and Entrepreneurship, 2(2), 113-135.

Kallmuenzer, A., \& Mike, P. (2018). Entrepreneurial behaviour, firm size and financial performance: The case of rural tourism family firms. Tourism Recreation Research, 43(1), $2-14$.

Kamasaka, R., Yavuzb, M., Karagullec, A. O., \& Agcad, T. (2016). Importance of strategic flexibility on the knowledge and innovation relationship: An Emerging Market Study. Conference proceedings on International Conference on Leadership, Technology, Innovation and Business Management, Available Online At www.sciencedirect.com.

Khantimirov, D. (2017). Market share as a measure of performance: Conceptual issues and financial accountability for marketing activities within a Firm. Journal of Research in Marketing, 7(3), 587-593.

Klein, G. A., \& Pierce, L. (2001). Adaptive teams. Retrieved from www.dtic.mil/cgibin/GetTRDoc?AD=ADA46774.

Kogo, P. K., \& Kimencu, L. (2018). Organizational capabilities and performance of insurance companies in Nairobi city county, Kenya. International Academic Journal of Human Resource and Business Administration, 3(1), 126-149.

Kraus, S., Rigtering, J. C., Hughes, M., \& Hosman, V. (2012). Entrepreneurial orientation and the business performance of SMEs: A quantitative study from the Netherlands. Review of Managerial Science, 6(2), 161-182.

Kuratko, D. F., \& Audretsch, D. B. (2009). Strategic entrepreneurship: Exploring different perspectives of an emerging concept. Entrepreneurship Theory and Practice, 33(1), 421430.

Lawal, F. A., Adegbuyi, O. A., Iyiola, O. O., Ayoade, O. E., \& Taiwo, A. A. (2018). Nexus between informal networks and risk-taking: Implications for improving the performance of small and medium enterprises (SMEs) in Nigeria. Academy of Strategic Management Journal, 17(2), 1-13. 
European Journal of Business and Innovation Research

Vol.8, No.2.pp. 1-19, April 2020

Published by ECRTD-UK

Print ISSN: 2053-4019(Print), Online ISSN: 2053-4027(Online)

Lee, J., \& Kim, B. C. (2013). The relationship between innovation and market share: Evidence from the global LCD industry. Industry and Innovation 20(1), 1-21.

Liyanage, A. S., \& Weerasinghe, T. D. (2018). The effect of strategic flexibilityon strategyperformance nexus: A conceptual model. Kelaniya Journal of Management, 07(1), 26-39.

Lomberg, C., Urbig, D., Stöckmann, C., Marino, L. D., \& Dickson, P. H. (2017). Entrepreneurial orientation: The dimensions' shared effects in explaining firm performance. Entrepreneurship Theory and Practice, 41(6), 973-998.

Makinde, O. G., \& Agu, C. U. (2018). Strategic entrepreneurship and performance of small and medium scale enterprises in Aba Metropolis. Archives of Business Research, 6(9), 49-69.

Manufacturers Association of Nigeria. (2018). Manufacturers Association of Nigeria Situation Report. MAN.

Micheal, A. (2016). Consumer buying behavior and market share of distributing firms in Lagos State. M.Sc. Thesis, Lagos State University, Ojo.

Mohammed, D., \& Obeleagu-Nzelibe, C. (2014). Entrepreneurial skills and profitability of small and medium enterprises (SMEs): Resource acquisition strategies for new ventures in Nigeria. Proceedings of 25th International Business Research Conference 13 - 14 January, 2014, Taj Hotel, Cape Town, South Africa.

Morgan, N. A (2009). Linking marketing capabilities with profit growth. International Journal of Research in Marketing, 26(4), 284-93.

Murtala, M., Ramatu, B., Yusuf, H. A., \& Gold K. L. (2018). Nigerian textile sector: Evidence of policy neglect. Sarjana, 33(1), 40-56.

Nigerian Textile Manufacturing Association. (2019). Nigerian Textile Manufacturers Association Competitiveness Assessment on Several Performance Indicators, Lagos.

Norzailan, Z., Yusof, S., \& Othman, R. (2016). Developing strategic leadership competencies. Journal of Advanced Management Science, 4(1), 36-51.

Nunnally, J. C. (1978). Psychometric theory ( $2^{\text {nd }}$ Ed). New York: Mcgraw-Hill.

Nyamao, O. R. (2016). The effect of strategic leadership on the performance of small and medium enterprises in Kenya. Ph.D. Thesis, University of Nairobi.

Odhong, E. A., \& Were, S. (2013). Human capital management as a tool for value creation. Proceedings of First SHRD Annual Research Conference, 12th and 13th September, Nairobi, Jomo Kenyatta University of Agriculture and Technology main campus.

Ogbari, M. E., Obigbemi, I. F., Atolagbe, T., \& Ojo, I. S. (2016). Strategic human resource development and entrepreneurial sustainability in Nigeria. Journal of Research in National Development, 14(1), 307-412.

Ogechi, R. N. (2016). The effect of strategic leadership on the performance of small and medium enterprises in Kenya. Ph.D. Thesis, University of Nairobi.

Okeowo, F. O. (2017). Trade liberalization and performance of the Nigerian textile sector (1986 - 2015). Ph.D. Thesis, Babcock University.

Okunbanjo, O. I., Adewale M. O., \& Akinsulire, H. O. (2017). Effect of entrepreneurs' character on SMEs performance in Lagos State. Journal of Management and Science, 7(3), 17-26.

Paek, B., \& Lee, H. (2017). Strategic entrepreneurship and competitive advantage of established firms: evidence from the digital TV industry. International Entrepreneurial Management Journal, 1, 1-43. 
European Journal of Business and Innovation Research

Vol.8, No.2.pp. 1-19, April 2020

Published by ECRTD-UK

Print ISSN: 2053-4019(Print), Online ISSN: 2053-4027(Online)

Patil, S. T., \& Marathe, S. (2016). Market orientation and flexibility in production planning in SMEs: An empirical study. International Research Journal of Multidisciplinary Studies 2(7), 2454-8499.

Peterson, S. J., Galvin, B. M., Lange, D. (2012). CEO servant leadership: Exploring executive characteristics and firm performance. Perspective Psychology, 65, 565-596.

Pleshko, L. P., \& Heiens, R. A. (2012). The market share impact of the fit between market leadership efforts and overall strategic aggressiveness. Business and Economics Research Journal, 3(3), 1-15.

Ployhart, R. E., \& Bliese, P. D. (2006). Individual adaptability (I-ADAPT) theory: Conceptualizing the antecedents, consequences, and measurement of individual differences in adaptability. In Burke, S., Pierce, L., \& Salas, E. (Eds.), Understanding adaptability: A prerequisite for effective performance within complex environments (pp. 3-40). St. Louis, MO: Elsevier Science.

Rubera, G., \& Kirca, A. H. (2012). Firm innovativeness and its performance outcomes: A metaanalytic review and theoretical integration. Journal of Marketing, 1, 36-49.

Sarutaya, S. (2015). Dynamic marketing capability and marketing survival: Evidence from auto parts businesses in Thailand. Business and Management Review, 7(1), 177 -188.

Serfontein, J. J. (2010). The impact of strategic leadership on the operational strategy and performance of business organisations in South Africa. Ph.D. Dissertation, University of Stellenbosch.

Shouyu, C. (2017). The relationship between innovation and firm performance: A literature review. Proceeding for 7th International Conference on Social Network, Communication and Education.

Sulaeman, A., Tisnawatisule, E., Hilmiana, H., \& Cahyandito, M. F. (2018). Determining SMEs business sustainability: Human resources management for sustainability approach. 1st International Conference on Economics, Business, Entrepreneurship, and Finance (ICEBEF 2018). Advances in Economics, Business and Management Research, 65, 764768.

Supeno, H., Sudharma, M., Aisjah, S., \& Laksmana, A. (2015).The effects of intellectual capital, strategic flexibility, and corporate culture on company performance: A study on small and micro-scaled enterprises (SMEs) in Gerbangkertosusila Region, East Java. International Business and Management, 11(1), 1-12.

Supriyadi, F. (2017). The influence of strategic leadership on firm inventive and innovative performance. Ph.D. Dissertation, University of Pittsburgh.

Takahashi, A. R., \& Semorebon, S. (2017). Dynamic capabilities, marketing capability and organisational performance. Brazilian Business Review, 14(5), 466-478.

Teece, D. J. (2019). A capability theory of the firm: an economics and (Strategic) management perspective. New Zealand Economic Papers, 53, 1, 1-43.

Theodosiou, M., Kehagias, J., \& Katsikea, E. (2012). Strategic orientations, marketing capabilities and firm performance: An empirical investigation in the context of frontline managers in service organisations. Industrial Marketing Management, 41(7), 1058-1070.

Ukenna, B. I., Makinde, G. O., Akinlabi, B. H., \& Asikhia, O. U. (2019). Strategic entrepreneurship and organisational performance of selected agricultural SMEs in Lagos, 
European Journal of Business and Innovation Research

Vol.8, No.2.pp. 1-19, April 2020

Published by ECRTD-UK

Print ISSN: 2053-4019(Print), Online ISSN: 2053-4027(Online)

Ogun and Oyo States Nigeria. International Journal of Development Strategies in Humanities, Management and Social Sciences, 9(3), 89-128.

Vorhies, D. W., Morgan, R. E., \& Autry, C. W. (2009). Product-market strategy and the marketing capabilities of the firm: Impact on market effectiveness and cash flow performance. Strategic Management Journal, 30(12), 1310-1334.

Vyas, V. (2009). Innovation and new product development by SMEs: An investigation of Scottish food and drinks Industry. PhD Thesis, Edinburgh Napier University.

Wang, H., Tsui, A. S., \& Xin, K. R. (2011). CEO leadership behaviors, organisational performance, and employees' attitudes. The Leadership Quarterly, 22(1), 92-105.

Westgren, R., \& Wuebker, R. (2019). An economic model of strategic entrepreneurship. Strategic Entrepreneurship Journal, 13(4), 507-528.

Woo, C. Y., \& Cooper, A. C. (2011). The surprising case for low market share. Harvard Business Review, 60, 106-113.

Yazan, E. A. (2018). Strategic flexibility and its impact on enhancing organisational effectiveness: An applied study on Jordanian hotels. International Business Research, 11(10), 165-173. 